\title{
'By his word'? Creation, preservation and consummation in the book of Hebrews
}

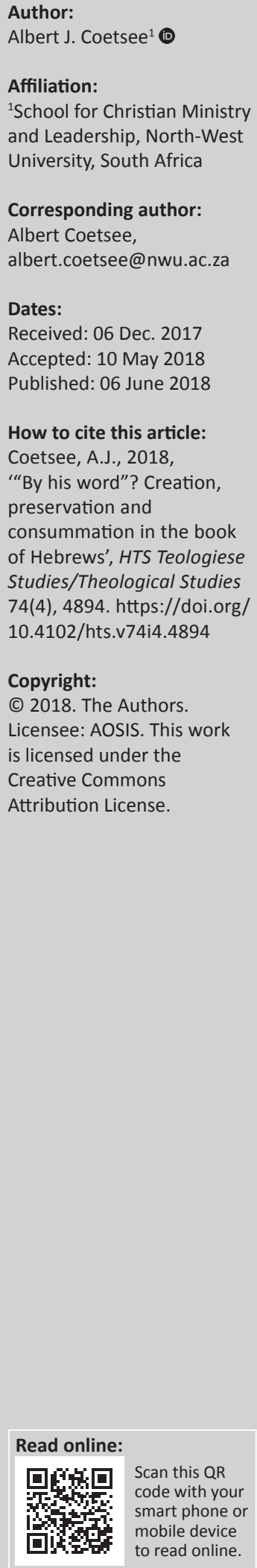

God's speech is a prominent theme in the book of Hebrews. A fascinating phenomenon regarding God's speech, and one that has in my opinion not been adequately explored, is that the writer possibly implies that God created by his word (Heb 11:3), preserves creation by his word (Heb 1:3) and will consummate creation by his word (Heb 12:26). This article examines whether the writer indeed had the conviction that God did, does and will do this by his word. This is done by doing grammatico-historical exegesis of Hebrews 11:3, 1:3 and 12:26 and integrating the findings. In so doing, this article contributes to the study of Hebrews' theology of God's word.

\section{Introduction}

God's speech is a prominent theme in the book of Hebrews. The anonymous writer starts his sermon with the striking statement that the same God who spoke in the past, has spoken by his Son (Heb 1:1-2a). This is followed up by numerous references to God's speech (amongst others by way of Old Testament introductory formulae), and the hearers' responsibility to listen obediently to what God says.

Consequently, various studies have been done on the theme of God's speech in the book of Hebrews. ${ }^{1}$ An interesting phenomenon regarding God's speech, and one that has in my opinion not been adequately explored, is that the writer possibly implies that God created by his word, preserves creation by his word and will consummate creation by his word. ${ }^{2}$ Three passages in Hebrews allude to this: ${ }^{3}$

- Hebrews 11:3 'By faith we understand that the universe was created by the word of God, so that what is seen was not made out of things that are visible' (creation).

- Hebrews 1:3 'He [the Son] is the radiance of the glory of God and the exact imprint of his nature, and he upholds the universe by the word of his power' (preservation).

- Hebrews 12:26 'At that time his voice shook the earth, but now he has promised, "Yet once more I will shake not only the earth but also the heavens"' (consummation).

Although Hebrews 12:26 does not contain a reference to God's word ( $\dot{\rho} \tilde{\eta} \mu \alpha)$, it does refer to God's voice ( $\varphi \omega v \eta \dot{)}$ and the consummation of creation. The synonymous nature of $\dot{\eta} \tilde{\mu} \alpha$ and $\varphi \omega v \eta$, together with the overall theme of God's speech in Hebrews, justifies a thematic link between 11:3, 1:3 and 12:26.

Consequently, the question arises: Does the writer indeed refer to God's creation, preservation and consummation by his word? And if he does, what is the exact nuance of this theme?

This article will contribute to the answer by doing grammatico-historical exegesis of Hebrews 11:3, 1:3 and 12:26. The various subsections of grammatico-historical exegesis will be limited to that which is relevant for the current investigation, and the subsections of exegesis will be presented in an order which allows the reader to follow the argument the best. The findings of this exegetical study will be integrated to formulate the writer's view of the theme. In so doing, this article will contribute to the study of Hebrews' theology of God's word.

\section{Did God create by his word? Hebrews 11:3 Introduction}

The first hypothesis to be investigated is whether the writer of Hebrews had the conviction that God created by his word. This is implied in Hebrews 11:3. Exegesis will start broad, namely 1.The most comprehensive studies are those of Wider (1997) and Lewicki (2004). Also see my (Afrikaans) doctoral dissertation: Coetsee (2014). 2.Some scholars note this phenomenon in the passing (e.g. MacArthur 2007:7), while others allude to it (cf. Cockerill 2012:660-673). 3.All English references to Scripture come from the English Standard Version. 


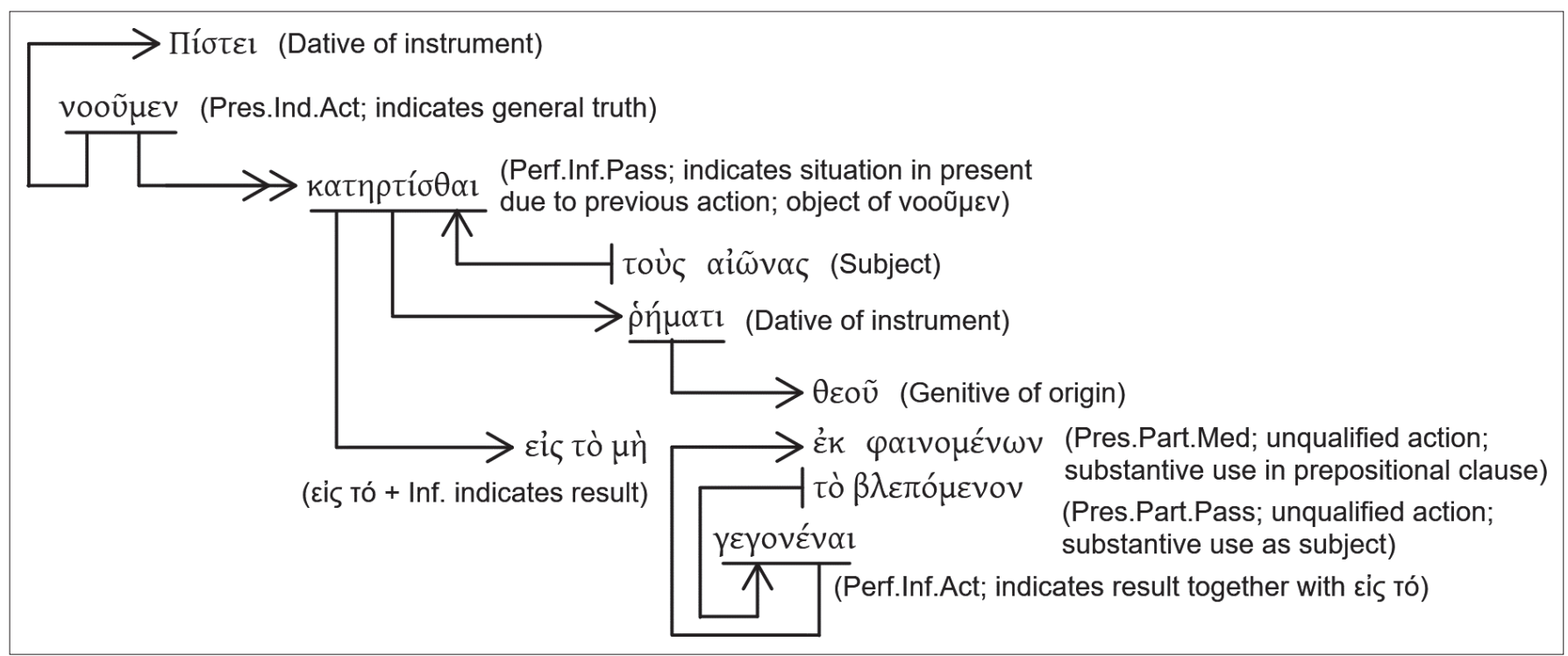

FIGURE 1: The syntactical analysis of Hebrews 11:3.

by determining the place of 11:3 within the sermon and by demarcating surrounding verses for further study.

\section{The place of Hebrews 11:3 within the sermon}

The writer of Hebrews follows up his great, central exposition on Jesus' high priestly ministry (7:1-10:18) with a number of chapters in which he primarily exhorts his hearers in different ways to persevere in faith (10:19-13:25). Because they were subjected to persecution and ostracism (10:32-34), some members of the faith community dwindled in their faith and threatened to become apostate. One of the manners in which the writer encourages them to persevere is by means of the example list of Hebrews 11:1-40. In this famous chapter, the writer lists various Old Testament heroes who persevered in faith in order to move his hearers to similar perseverance in their current situation. ${ }^{4}$

The example list of Hebrews 11 revolves around the characteristic term $\pi$ í $\tau \iota \varsigma$, which is found 24 times in the chapter (of which 18 are in the form of the anaphoric dative of instrument $\pi i ́ \tau \tau \varepsilon 1)$. The chapter, which is demarcated by

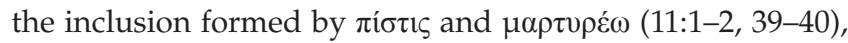
can be subdivided into four sections (cf. Attridge 1989:307; Cockerill 2012:518-519):

- 11:1-7 forms the introduction of the example list by giving a working definition of faith and describing the period from creation to Noah (cf. Gen 1-11).

- 11:8-22 focuses mainly on Abraham and, to a lesser extent, on Isaac, Jacob, Joseph and Sarah (cf. Gen 12-50).

- 11:23-31 focuses primarily on Moses and briefly on the conquest of the Promised Land (Ex-Josh), and

- 11:32-40 gives a brief overview of history from the judges to Christ and contains the conclusion of the example list.

Consequently, Hebrews 11:3 should be interpreted in the light of 11:1-7.

4.See the excellent studies of Cosby (1988) and Eisenbaum (1997).

\section{A syntactical analysis of Hebrews 11:3}

Moving from the bigger picture of 11:1-7 to the detail of 11:3, it is important to understand the relationship between and nuance of the various words that make up Hebrews 11:3. For this, a syntactical analysis must be done. The syntactical analysis of Hebrews 11:3 can visually be presented as in Figure $1 .^{5}$

Just like verses 4,5 and 7 , verse 3 starts with the anaphoric dative of instrument $\pi$ í $\tau \varepsilon \varepsilon$, which makes the continuity between verse 3 and the rest clear. From the context, the present indicative voov $\mu \varepsilon v$ has the nuance of a general truth.

The position of the negative $\mu$ í within the prepositional clause is a subject of much debate. Some argue that $\mu$ í

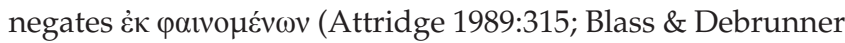
1961:§433[3]; Ellingworth 1993:568; Moffatt 1924:161), while

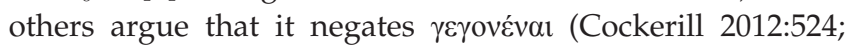
Hughes 1977:443; Lane 1991b:326-327). This syntactical

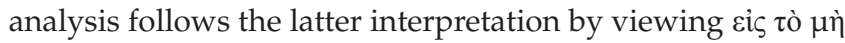

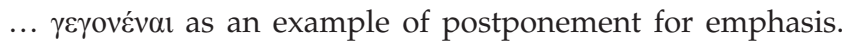
The present participle tò $\beta \lambda \varepsilon \pi$ ó $\mu \varepsilon v o v$ is used substantively as the subject of $\gamma \varepsilon \gamma \mathrm{\sigma}$ ह́val.

When taking the above into account, the sentence can be translated as 'By faith we understand that the world/times was created by the word of God, so that what is seen did not come to be from visible things'.

\section{A semantic analysis of Hebrews 11:3}

A correct understanding of the phrase $\pi i ́ \sigma \tau \varepsilon \iota$ vooṽ $\mu \varepsilon v$

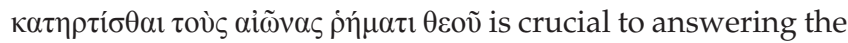
question of whether the writer of Hebrews had the conviction that God created by his word. In order to correctly understand this phrase, it is necessary to do word study of voź $\omega, \kappa \alpha \tau \alpha \rho \tau i \zeta \omega$,

5.This visual exposition of the syntactical analysis of a pericope is based on the method developed by Janse van Rensburg (1980). 
aióv and $\dot{\rho} \tilde{\eta} \mu \alpha$. Because the context of the one word is influenced by the presence of the other, these words are studied together.

Since its origin, the verb voź $\omega$ refers to mental perception (cf. TDNT 1976:4:948-951). The three ways in which voź $\omega$ is used in the New Testament give evidence to this fact (BDAG 2000:674-675; L\&N 32.2, 30.3, 31.6; LSJ 1996:1177-1178): it refers to understanding something on the basis of careful consideration (i.e. 'to understand' or 'to perceive'), to carefully think about something (i.e. 'to consider' or 'to think about') or to form an idea about something ('to imagine'). In the light of this, the verb voć $\omega$ in 11:3 most naturally has the nuance of mental perception. This is how Louw and Nida (32.2) interpret voć $\omega$ in the context of 11:3: it refers to mental observation on the basis of careful consideration. This mental perception is qualified by the dative of instrument $\pi$ í $\tau \varepsilon \varepsilon$, by which the writer, writing from the perspective of a firstcentury Christian, makes it clear that this mental perception comes only through faith.

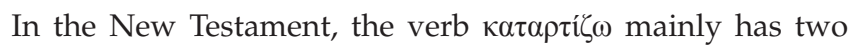
nuances: it either refers to the act of enabling something of someone to function properly, namely 'to make sufficient' or refers to the act of preparing something or someone for a specific task, namely 'to prepare', 'to create' or 'to equip' (BDAG 2000:526; L\&N 75.5, 13.130, 42.36; LSJ 1996:910). The three occurrences of $\kappa \alpha \tau \alpha \rho \tau i \xi \omega$ in Hebrews each follow the latter use:

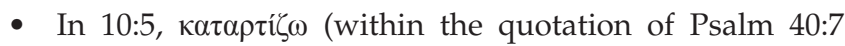
[LXX 39:7]) refers to the body that God 'prepared' or 'created' for Christ.

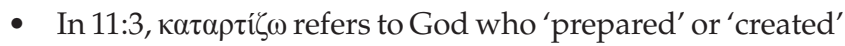

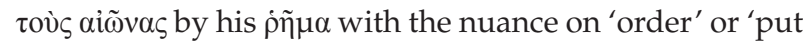
into proper condition' (L\&N 42.36).

- In 13:21, $\kappa \alpha \tau \alpha \rho \tau i \zeta \omega$, found within the writer's concluding benediction, refers to the prayer that God 'equip' the hearers with everything that is good.

The noun $\dot{\rho} \tilde{\eta} \mu \alpha$ usually refers to that which has been said, namely a word, saying, expression or statement (BDAG 2000:905; LSJ 1996:1569). It often refers to a single word (L\&N 33.9). The basic meaning of the root in the Greek world is something that is said with certainty (TDNT 1976:4:75-76). In the LXX, $\dot{\rho} \tilde{\mu} \alpha$ and $\lambda$ ó synonyms (primarily as the translation of makes it difficult to distinguish between the two nouns in the New Testament. Further investigation makes it clear that $\dot{\rho} \tilde{\eta} \mu \alpha$ occurs 4 times in Hebrews $(1: 3 ; 6: 5 ; 11: 3 ; 12: 19)$ and $\lambda$ ó $о$ o 12 times $(2: 2 ; 4: 2,12,13 ; 5: 11,13 ; 6: 1 ; 7: 28 ; 12: 19$; $13: 7,17,22)$. Even closer examination reveals that the writer of Hebrews uses $\dot{\rho} \tilde{\mu} \alpha$ exclusively to refer to God's

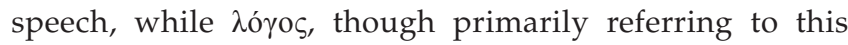
theme, is used in various manners (Ellingworth 1993:101; cf. Coetsee 2014:271). In the current context, $\dot{\rho} \tilde{\mu} \alpha$ is followed by the genitive of origin $\theta \varepsilon 0 \tilde{v}$, which confirms that $\dot{\rho} \tilde{\mu} \alpha \theta \varepsilon$ ov in 11: 3 refers to 'the word of God' or 'the word spoken by God'.
In general, aív has two semantic applications in the New Testament:

- The most common semantic use of $\alpha i \omega v$ is temporal in nature: it refers to a period of existence, namely a specific unit of time (LSJ 1996:45). As such, it may refer to a long period of time, without reference to beginning or end, like 'the earliest times' or 'eternity' (BDAG 2000:32). On the other hand, it may also refer to a specific stage or period in history, such as a lifetime, a period, an era or a generation (L\&N 67.143). The idea of a period implies that there is a series of $\alpha i \tilde{\omega} v \varepsilon \varsigma$. The New Testament writers shared the idea of human history being divided into two eras, with the commencement of the new era with the life, death, resurrection and glorification of Christ (TDNT 1976:1:204).

- Aióv also developed another semantic application, namely as a description for the spatial world. As such,

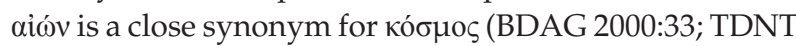
1976:1:203).

The question remains whether aióv in 11:3 is used in a temporal or spatial manner. There is a close connection

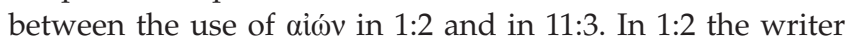
states that God created $\tau$ ov̀ $\alpha i \tilde{\omega} v a s$ through his Son. In my opinion, Allen (2010b:151) argues convincingly that the writer uses aíw in 1:2 in both a spatial and temporal sense: through his Son as agent God created both periods of time and the spatial world. ${ }^{6}$ The fact that 11:3 states that 'the word

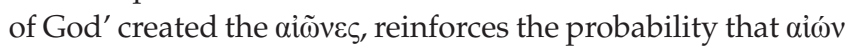
in 11:3 refers to periods and the spatial world (cf. Bruce 1990:279; Cockerill 2012:523-524). However, it is especially the visible character of the spatial world that is emphasised

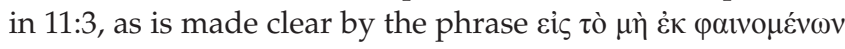

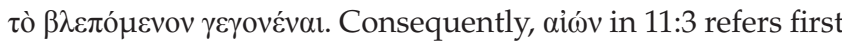
and foremost to the spatial world.

Considering all of above, it is possible to form a more

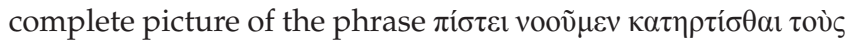

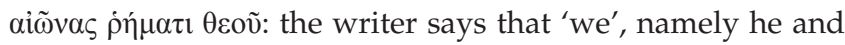
his hearers, by faith alone understand that the spatial world was created by the word of God. Undoubtedly, this phrase refers to God's performative words of creation in Genesis 1. The emphasis in 11:3 is on faith: the reality of creation cannot be reached by human senses, but only by the type of mental perception that is possible by faith (TDNT 1976:4:951; cf. Wider 1997:188). Faith enables one to understand that the visible universe was created by something invisible, namely by the word of God (Ellingworth 1993:568; cf. Hughes 1972:64-77). The overall context of Hebrews supports Lane's (1991b:331) statement that the medium for this mental

6.Allen $(2010 \mathrm{~b})$ says the following: If both "world" and 'age' are legitimate renderings of aíwv, and if a good case could be made for either possibility, perhaps the real problem with translating [Hebrews] $1.2 \mathrm{c}$ lies with the modern, or receivin language, rather than with the specific Greek word ... A more effective rendering, however, albeit one verging towards paraphrase, would be something akin to 'through whom he also created all times and space' (p. 151).

7.Genesis 1:3,6, 9, 11, 14, 20, 24, 26. Cf. Psalm 33:6, 9 (LXX 32:6,9), Sirach 42:15 Wisdom $9: 1$ and John 1:3. It is highly unlikely that pंñ $\mu \alpha$ in $11: 3$ should be understood as a reference to Christ as $\lambda$ óyoç in John 1:1 (cf. Bruce 1990:279; Koester 2001:473). That the first chapter of Genesis in the writer's mind is confirmed by the fact that the first three heroes of faith (Abel, Enoch and Noah) in Hebrews 11:4-7 come from consecutive chapters of Genesis (Gen 4-9). 
perception is the written word of God, 'which activates the capacity for religious knowledge intrinsic to faith'.

\section{A thought structure analysis of Hebrews 11:1-7}

In order to confirm the above interpretation of the phrase

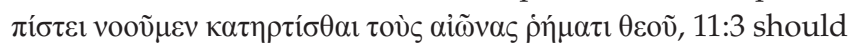
be checked against the context of 11:1-7 by means of a thought structure analysis. Such an analysis has the added advantage of supplementing our understanding of the phrase.

A thought structure analysis of Hebrews 11:1-7 can visually be presented as in Figure 2.

The writer of Hebrews starts chapter 11 by giving a definition of faith. As Ellingworth (1993:566) indicates, the writer's purpose is not to give a comprehensive definition of faith. Rather, the purpose of his definition is to state what faith does: it enables one to know and to see things that otherwise cannot be known and seen. Using the conjunction $\gamma \alpha \dot{\alpha} \rho, 11: 1$ is coupled with 11:2, which confirms the definition just given and introduces another motive, namely that of 'giving evidence' ( $\mu \alpha \rho \tau \nu \rho \varepsilon ́ \omega ; ~ c f . ~ 11: 4,5,39)$. Consequently, 11:1-2 can be seen as the introduction of Hebrews 11:1-40.

The first appearance of the anaphoric dative of instrument $\pi i ́ \sigma \tau \varepsilon$ is found in 11:3 (cf. 11:4-31). The verse refers to God who created by speaking. As the beginning of the Old Testament Scriptures, the reference to Genesis 1 is highly appropriate. Yet this verse is unique within the structure of 11:1-40. Unlike 11:4-38 which follows, 11:3 does not have an Old Testament hero of faith as subject, but the first person plural 'we' (vooṽ $\mu \varepsilon v)$. Consequently, 11:3 serves as a transitional verse between the introduction with its definition of faith (11:1-2) and the description of the various heroes of faith (11:4-38; cf. Lane 1991b:321; Wider 1997:188-190). This verse links directly with 11:1's description of faith as

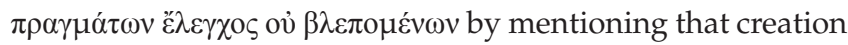

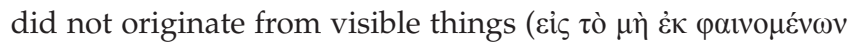

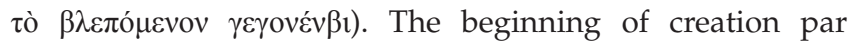
excellence serves as one of the things that cannot be seen and which can only be understood by faith. With this verse,

THEME: Faith is objective proof of things that cannot be seen DEFINITION of faith

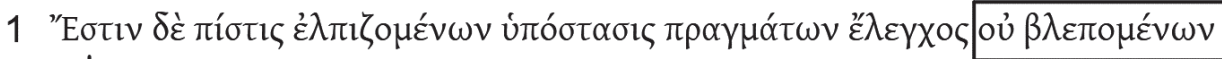

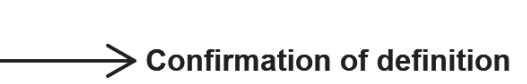

2

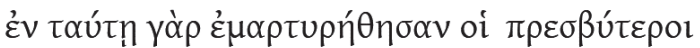

TRANSITIONAL VERSE: The visible from invisible things

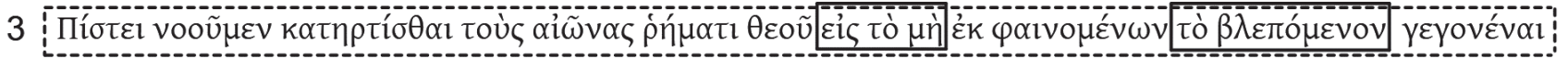

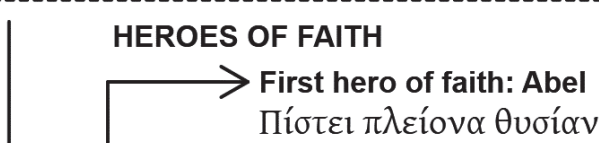

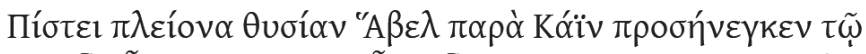

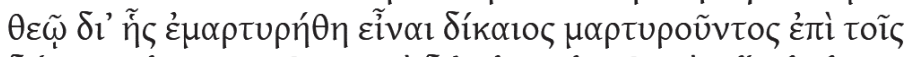

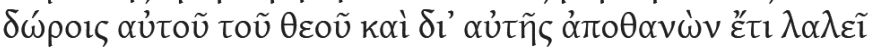

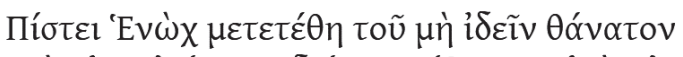

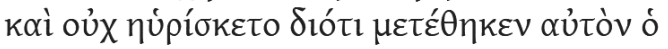

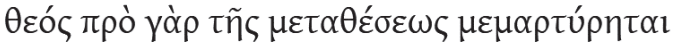

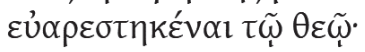

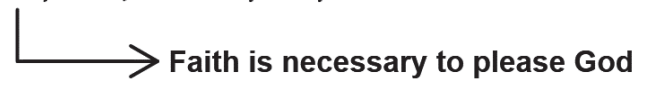

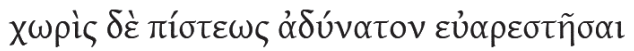

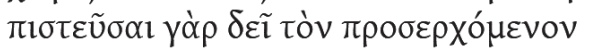

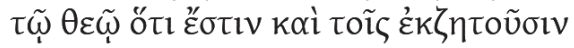

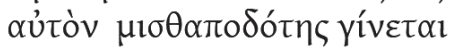

\section{Third hero of faith: Noah}

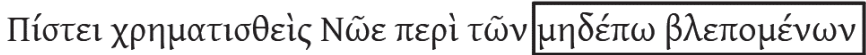

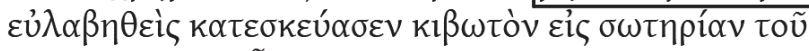

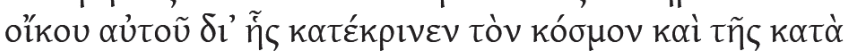

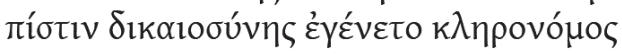


the writer links his hearers' faith directly to those of the Old Testament heroes of faith in 11:4-38.

The long list of heroes of faith from the Old Testament starts at 11:4, which links directly to $\dot{\varepsilon} \mu \beta \rho \tau v \rho \eta \dot{\theta} \theta \eta \sigma \alpha v$ oi $\pi \rho \varepsilon \sigma \beta v i \varepsilon \rho \rho$ เ in 11:2. Abel serves as the first hero of faith. Enoch follows in 11:5. Before continuing to the next hero, the description of Enoch pleasing God is stated as general principle of faith in 11:6. Lastly, Noah is given as hero of faith in 11:7, and once

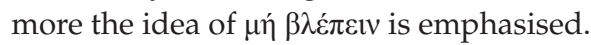

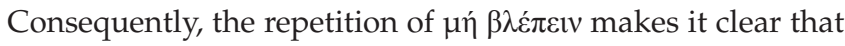
Hebrews 11:1-7 focuses primarily on the second part of the

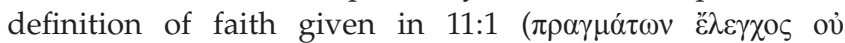
$\beta \lambda \varepsilon \pi \mathrm{o} \mu \varepsilon \dot{v}(\omega v)$. The theme of these verses can be summarised with the descriptive heading 'Faith is the objective proof of the things that cannot be seen'.

\section{Other references to creation in Hebrews}

Finally, before reaching a conclusion about the writer's conviction regarding creation by God's word, the reference to creation in 11:3 should be viewed against all other references to creation in Hebrews. Hebrews contains four other references to God's creative work, namely 1:2, 1:10-12, 4:3 and 9:26.

\section{Hebrews 1:2}

In another article, I argue that Hebrews 1:1-4 can be divided into two parts: 1:1-2a and 1:2b-4 (Coetsee 2016:5-6). Hebrews 1:1-2a speaks about God's superior revelation in his Son, while Hebrews 1:2b-4 gives seven descriptions of who the Son is and why God could reveal himself superiorly in him. One of these descriptions is the phrase $\delta \imath^{\prime}$ oṽ кaì

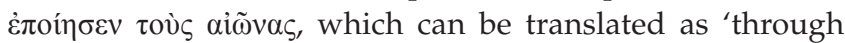
him [the Son] he [God] made the spatial world/periods'. As argued above, aióv in this context refers to the spatial world and periods.

The writer's statement in Hebrews 1:2 that God made the spatial world and periods agrees with his statement in Hebrews 11:3 of God creating the universe. What makes $1: 2$ unique is the writer's description that God created 'through' his Son; the Son was God's agent of creation. In conjunction with other New Testament passages (Jn 1:3, 10; 1 Cor 8:6; Col 1:16), the writer of Hebrews emphasises that the Son is not made, but he is the Maker of all things (Webster 2009:84).

\section{Hebrews 1:10-12}

In Hebrews 1:5-14, the writer compares the Son's excellence to that of the angels by way of seven quotations from the Old Testament. In the sixth quotation (Heb 1:10-12) the writer quotes from Psalm 102:25-27 (LXX 101:26-28). Of special interest here is the reference to God's creative acts in Psalm 102:25 as quoted in Hebrews 1:10:

You, Lord, laid the foundation of the earth in the beginning, and the heavens are the work of your hands.
What is especially worth noting is the fact that the writer of Hebrews introduces this quotation by stating that God says these specific words 'of the Son' (taking into account the connection between the introductory formulae in 1:8 and $1: 10)$. Moreover, the use of the second person singular and the vocative in the quoted verse makes it clear that in the mind of the writer of Hebrews, God is speaking these words to his Son. And what makes this important for the purpose of this article is the fact that in the words of Psalm 102:25 God calls his Son 'Lord' ( $\kappa$ pros) and states that he is the Creator. In the light of Hebrews 1:2, the writer is referring to the Son's agency at creation.

\section{Hebrews 4:3}

In 4:1-11 the writer of Hebrews argues that the promise of eschatological 'rest' remains for those who believe and exhorts his hearers not to miss this opportunity as a result of negligence. This is done in part in 4:1-5 by verbal analogy: the writer explains the meaning of 'rest' in Psalm 95 by means of referring to and quoting from Genesis 2:2, which refers to God's rest on the seventh day. In the midst of this argument, the writer refers to God's finished works 'since the foundation

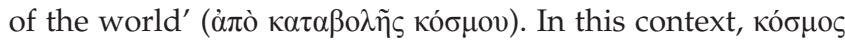
refers 'to universe as an ordered structure' (L\&N 1.1; cf. BDAG 2000:561) and functions as a close synonym for

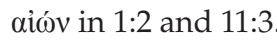

For the sake of this article, it is sufficient to note that $4: 3$ confirms the writer's conviction that God created the world. Moreover, by way of deduction, the writer shared the conviction that God, as recorded in Genesis 1-2, created the world in 6 days.

\section{Hebrews 9:26}

Hebrews 9:23-10:18 describes how Christ, in contrast to the perpetual Old Testament sacrifices that could never completely remove sin, willingly sacrificed himself once and for all to completely provide forgiveness for sin. Hebrews 9:25-26 focuses on the single occurrence ( $\left.\alpha^{\pi} \pi \xi\right)$ of Christ's sacrifice in contrast to the annual entrance of the high priest into the Holy of Holies. The emphasis falls on the fact that Christ is not exactly like the earthly high priests. If he were, he would have had to offer himself repeatedly 'since the

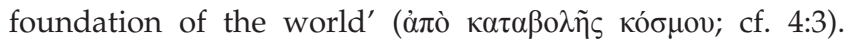
Attridge (1989:264) rightly says that his note 'simply emphasizes the absurdity of the proposition'.

Consequently, the reference to creation in 9:26 is not of special interest for this article. It does, however, confirm by way of analogy the writer's conviction that creation had a definite beginning.

\section{Conclusion}

The results of this exegetical study confirm that the writer of Hebrews indeed had the conviction that God created by hermeneutical principles traditionally attributed to Rabbi Hillel (Guthrie 2003:282). 
his word. In 11:3 he states that he and his hearers have the mental perception given by and grounded on faith that God, as recorded in Genesis 1, created the spatial world by his performative words of creation. In 1:2 and 1:10-12 the writer's conviction is expounded: he views the Son as God's agent of creation; God created through his Son. Consequently, the writer's conviction of creation can be summarised as follows:

The writer of Hebrews was convinced that the Son was the agent of the creation of the spatial world and periods of time (1:2) that came to be by God's performative word (11:3).

\section{Does God preserve creation by his word? Hebrews 1:3}

The second hypothesis that has to be investigated for the purposes of this article is whether the writer of Hebrews had the conviction that God preserves creation by his word. This is implied in Hebrews 1:3:

He [the Son] is the radiance of the glory of God and the exact imprint of his nature, and he upholds the universe by the word of his power.

As with the exegesis of 11:3, the exegesis of 1:3 will start broad by determining the place of the verse within the sermon, followed up by a brief thought structure analysis of the pericope it forms part of. From this broad investigation, the focus will shift to a detailed analysis of 1:3.

\section{The place of Hebrews 1:3 within the sermon}

There is consensus amongst modern scholars that Hebrews 1:1-4 forms the introduction or exordium of the sermon. This pericope is distinguished from 1:5-14, which, by means of a comparison between the Son and the angels, emphasises the Son's supremacy. Consequently, the place that 1:1-4 occupies within the sermon is easily determinable: it is the first words of Hebrews, and as such, it immediately and emphatically attracts the attention of the hearers.

\section{A thought structure analysis of Hebrews 1:1-4}

As stated earlier, Hebrews 1:1-4 can be divided into two parts: $1: 1-2 a$ and $1: 2 b-4$. The latter gives seven descriptions of who the Son is, and why God could reveal himself

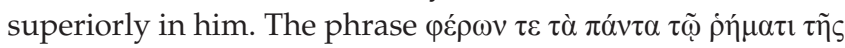

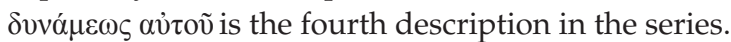

For the purpose of this study, it is sufficient to note that the phrase under investigation is one of the phrases that describe the supremacy of the Son.

\section{The text critical note at Hebrews 1:3}

Unlike the text of Hebrews 11:3, the text of Hebrews 1:3 contains a text critical note in the UBS5 edition of the

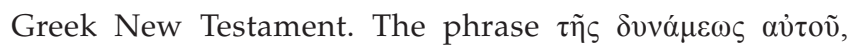
$\kappa \alpha \theta \alpha \rho ı \mu$ òv has a $\{\mathrm{B}\}$ level of certainty, which means that the editors are almost certain of the reading. However,

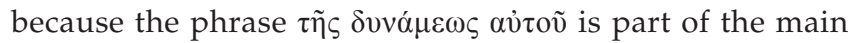

TABLE 1: Two variant readings.

\begin{tabular}{|c|c|c|c|}
\hline Language & UBS5 & Variant \#1 & Variant \#2 \\
\hline Greek & 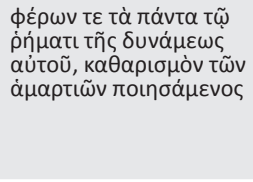 & 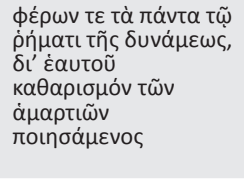 & 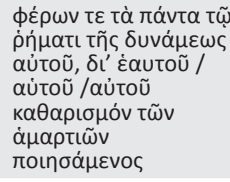 \\
\hline English & $\begin{array}{l}\ldots \text { and carries all things } \\
\text { by the word of his } \\
\text { power, after making } \\
\text { purification for sins ... }\end{array}$ & $\begin{array}{l}\ldots \text { and carries all } \\
\text { things by the word of } \\
\text { the power, after } \\
\text { making purification } \\
\text { for sins by himself ... }\end{array}$ & $\begin{array}{l}\ldots \text { and carries all } \\
\text { things by the word of } \\
\text { his power, after } \\
\text { making purification } \\
\text { for sins by himself... }\end{array}$ \\
\hline
\end{tabular}

clause under investigation, the text critical note needs to be investigated (Table 1).

Variant reading \#2 can be attributed to conflation between the UBS5 reading and variant reading \#1. As such, more attention should be given to the first variant reading.

It is noteworthy that variant reading \#1 enjoys the support of the early $\mathrm{P}^{46}$. However, Metzger (1994:592) argues

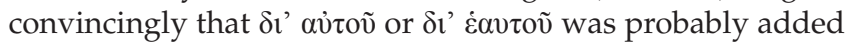
later to emphasise the middle voice of the ambiguous $\pi$ om $\sigma \alpha \dot{\mu} \varepsilon v o \varsigma$. The addition of these words confirms Christ's self-sacrifice (cf. Attridge 1989:35; Allen 2010a:124; Ellingworth 1993:101; Lane 1991a:5). It is less likely that

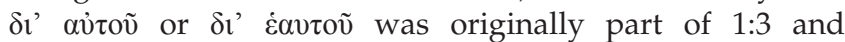
was accidentally deleted by good representatives of the Alexandrian text ( $\mathrm{A} \mathrm{B} 33$ 81) and Western sources (it ${ }^{81} \mathrm{vg}$ ).

In my view, it is therefore best to follow the UBS5 reading.

\section{A syntactical analysis of Hebrews 1:3}

A detailed analysis of Hebrews 1:3 will greatly be helped by a syntactical analysis of the verse. The syntactical analysis of Hebrews 1:3 can visually be presented as in Figure 3.

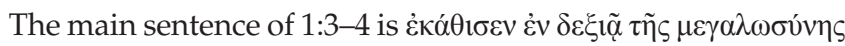

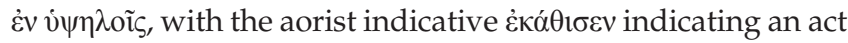
in the past. This main clause is preceded by three clauses: the

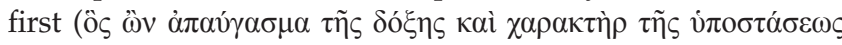

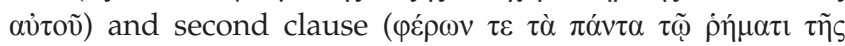

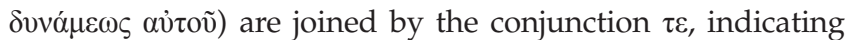
the close relationship between them..$^{9}$ In near hymnal fashion, ${ }^{10}$ these two phrases describe the eternity of the Son, specifically his eternal status and his eternal activity. Consequently, both present participles ( $\omega v$ and $\varphi \varepsilon ́ \rho \omega v$ ) indicate timeless actions (cf. Ellingworth 1993:98; Mackie 2008:446). ${ }^{11}$ The aorist

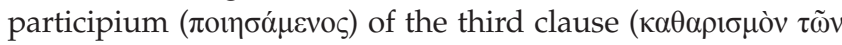

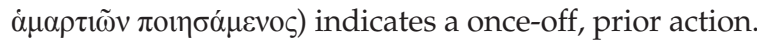

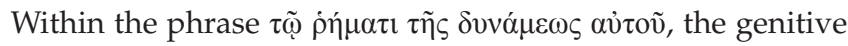
$\tau \tilde{\eta} \varsigma \delta v v \alpha ́ \mu \varepsilon \omega \varsigma$ is a genitive of quality, namely, a Hebraism

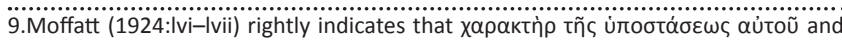

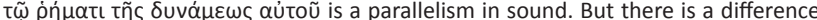
between the phrases: the first aútoũ refers to God, and the second to the Son.

10.Ebert (1992:175-176) gives a good explanation of why some scholars view Hebrews $1: 3$ as part of an ancient hymn. While the hymnal nature of $1: 3$ is clear, he argues that it is unlikely that the writer simply integrated an existing hymn.

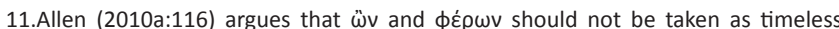

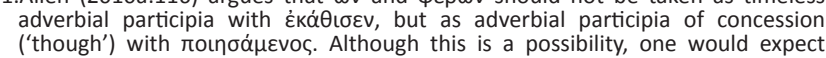
clearer indications if concession was in the writer's mind. 


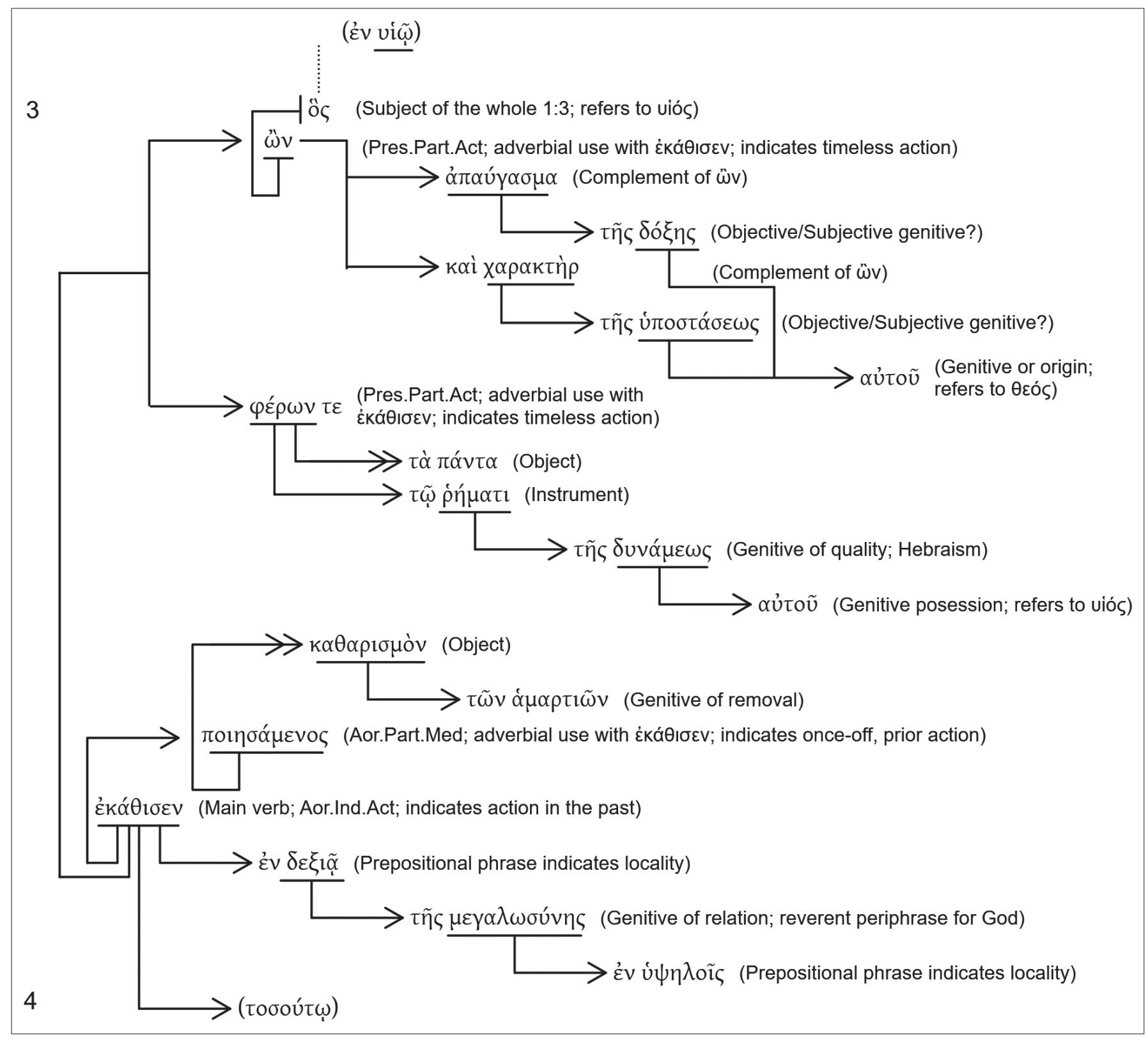

FIGURE 3: The syntactical analysis of Hebrews 1:3.

where the genitive functions as an adjective (cf. Black 1987:190; Blass \& Debrunner 1961:§165; Cockerill 2012:95). Consequently, instead of translating the phrase as 'by the word of his power', it is better to translate it as 'by his powerful word'.

\section{A semantic analysis of Hebrews 1:3}

In order to confirm whether the writer had the conviction that God preserves creation by his word, semantic analysis

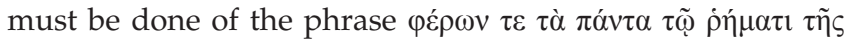

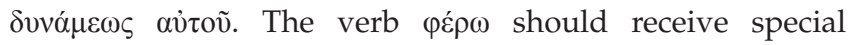
attention because it gives rise to the interpretation that God preserves creation.

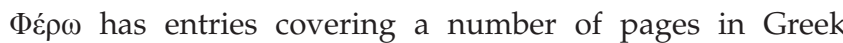
dictionaries: LSJ (1996:1922-1924), Louw and Nida (1996:256) and BDAG (2000:1051-1052) each list 10 or more possibilities for the meaning of the verb. The most common use of $\varphi \varepsilon ́ p \omega$ is to refer to the act of carrying or bringing something from one place to another. Other general semantic applications of $\varphi \varepsilon ́ p \omega$ are to guide or lead something or someone, or to endure or tolerate something or someone. According to major dictionaries, however, the use of $\varphi \varepsilon ́ \rho \omega$ in 1:3 is less common: it refers to the act of 'sustaining' or 'maintaining' (BDAG 2000:1052; L\&N 13.35; TDNT 1976:9:59). Not only does the context support this interpretation but it also elaborates on how the reader should understand the reference to

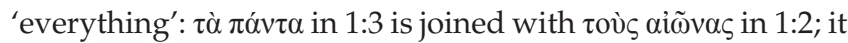
refers to 'all things' of the spatial world and periods (Moffatt

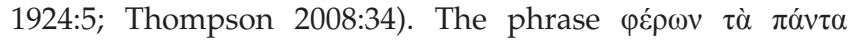
therefore states that the Son maintains everything in the universe.

However, scholars are quick to warn that one should not think that the Son carries the dead weight of the world on his 
shoulders like Atlas carries the heavens in Greek mythology. The nuance of $\varphi \varepsilon ́ \rho \omega$ is not static at all, but dynamic: the Son sustains the universe in his providence and leads it forward on its determined course to the consummation (Bruce 1990:49; Cockerill 2012:95; Allen 2010a:122; Hughes 1977:45; MacLeod 2005:222-223).

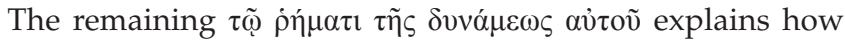
the Son sustains everything in the universe: he sustains it by his powerful (sovereign), preserving word (Wider 1997:49). Strictly speaking, the writer could merely have stated that

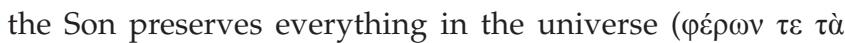

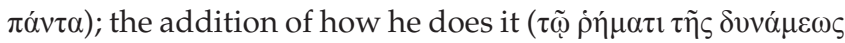

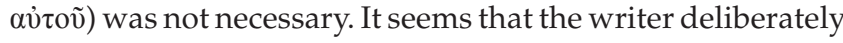
added this description to unite the pericope (Allen 2010a:123): God spoke in his Son (1:1-2a); the Son was the agent of creation that came about through God's speech (1:2b; cf. Gen 1); now the Son maintains the universe by his powerful word (1:3b). ${ }^{12}$

But what does the Son's powerful word refer to? Most commentators are silent on the matter. While most interpret $1: 3 b$ as a reference to Christ's sustaining activity, only a handful give a closer description of what the Son's 'word' refers to. The most convincing interpretation is that it refers to 'the expression of his will' (Hughes 1977:46) or 'the enactment of his will' (Webster 2009:89). The Son sustains everything in the universe by his will.

The emphasis, however, does not fall on $\dot{\rho} \tilde{\eta} \mu \alpha$, but on the genitive of quality $\tau \tilde{\eta} \varsigma \delta v v \alpha ́ \mu \varepsilon \omega \varsigma$. The Son sustains everything by his powerful word or will. His word or will is 'divinely potent and effective' (Webster 2009:89). What he says or wants, is done. Or as Kistemaker (1984:30) aptly puts it, he carries all things 'by a mere utterance'. ${ }^{13}$

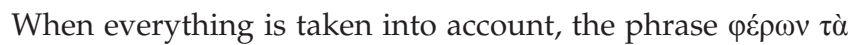

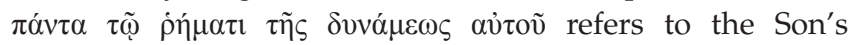
preservation of everything in the universe through his powerful word. This means that the exordium of Hebrews not only highlights that the Son was God's agent of creation (1:2b) but also emphasises that the Son sustains everything in creation (1:3b). ${ }^{14}$ Or to state it differently: the Son is not only Creator but also Sustainer (cf. Hughes 1977:46; Kistemaker 1984:30; MacLeod 2005:223). Moreover, the fact that $\varphi \varepsilon ́ p \omega v$ is a present participle indicates that the Son's maintenance of creation is an ongoing activity (Meier 1985:182-183). Hebrews 1:3 describes 'the ongoing sustaining activity of the agent of creation' (Attridge 1989:45).

12.This links closely with Colossians 1:17, which says: 'And he is before all things, and in him all things hold together'. The whole universe holds together in the Son.

13.Calvin's (1853:22) explanation of the implications of this phrase is striking: he argues that 'word' in 1:3 'means simply a nod ... that Christ ... preserves the whole world by a nod only ...'.

14.In my view, Cockerill (2012:95) goes too far by saying that 'The Son sustains the world by the same word through which it was created (compare 11:3)' (emphasis mine), so does Webster (2009.89): "This powerful word is a reiteration and (extension of the creative word which bestowed structure upon creation (11.3) (emphasis mine). While the link between 1.3 and 11.3 is clear, pñ $\mu \alpha$ in $1: 3$ canno simply be equated with $\dot{\rho} \tilde{n} \mu \alpha$ in 11:3. The context of $\dot{\rho} \tilde{\eta} \mu \alpha$ should be taken into account when interpreting the meaning of the word in both 1:3 and 11:3.

\section{Other references to God's preservation of creation in Hebrews}

Unlike references to God's creation and God's consummation of creation, there are no explicit or implicit references to God's preservation of creation in Hebrews apart from 1:3.

\section{Conclusion}

Exegesis of Hebrews 1:3 confirms that the writer of Hebrews had the conviction that God sustains creation by his word. More specifically:

The writer was convinced that the Son continually sustains everything in the universe by his powerful word.

\section{Will God consummate creation by his word? Hebrews 12:26 Introduction}

Up to this point exegesis has shown that the writer of Hebrews was convinced that the Son was the agent of the creation of the spatial world and periods (1:2) that came to be by God's performative word (11:3; cf. Gen 1) and that the Son continually sustains everything in the universe by his powerful word (1:3). It remains to be seen whether the writer had the conviction that God will consummate creation by his word. This is possibly implied in Hebrews 12:26:

At that time his voice shook the earth, but now he has promised, 'Yet once more I will shake not only the earth but also the heavens'.

As stated in the introduction, although Hebrews 12:26 does not contain a reference to God's word ( $\dot{\rho} \tilde{\mu} \mu \alpha)$, but to his voice ( $\varphi v \vee \eta)$, the synonymous nature of $\dot{\rho} \tilde{\mu} \mu \alpha$ and $\varphi \omega v \eta ́$ justifies an investigation of Hebrews 12:26 for the possible conviction of God consummating creation by his word.

\section{A thought structure analysis of Hebrews 12:14-29}

As with exegesis of 11:3 and 1:3, exegesis of 12:26 should start broad. Hebrews 12:26 forms part of the longer and complex pericope 12:14-29. Because the current investigation focuses on the question whether 12:26 refers to God consummating creation by his word, it is sufficient to give a thought structure analysis of 12:14-29 before focusing on specific questions regarding 12:26.

A thought structure analysis of Hebrews 12:14-29 can visually be presented as in Figure 4 .

The writer of Hebrews follows up his encouragement to faithfulness by means of the example list of 11:1-40 by exhorting his hearers in 12:1-13 to persevere in trials as Jesus did. In the very next pericope, namely 12:14-29, he brings his call for perseverance to a climax. Closer examination reveals that 12:14-29 can be divided into three subsections, namely 12:14-17, 12:18-24 and 12:25-29 (cf. Coetsee 2015:2):

- 12:14-17 forms the introduction of the whole. From the general exhortation to pursue peace and sanctification 


\section{THEME: Make sure you do not reject him who speaks more superiorly to you under the new covenant}

\section{2:14-17 INTRODUCTORY WARNING: Continually care for one another in the face of possible apostasy}

General exhortation for peace and sanctification

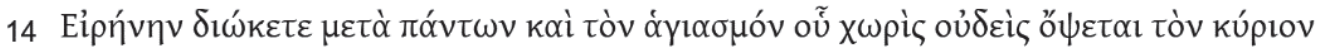

Specific exhortation to be vigilant

1 General warning

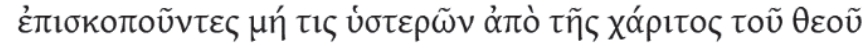

2 Warning against apostasy

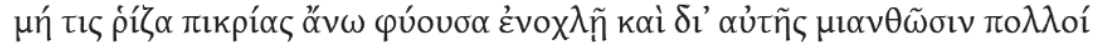

3 Esau as example of apostasy

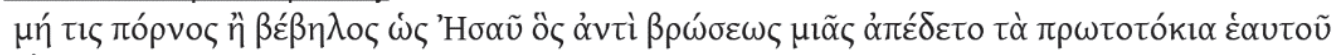

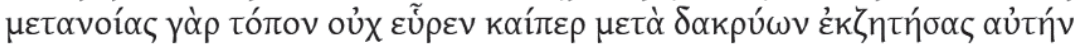

\section{2:18-24 EXPLANATION: Realise your beneficial situation under the new covenant}

12:18-21 The terrifying situation of the confirmation of the covenant at Sinai

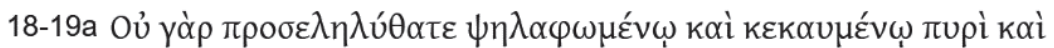

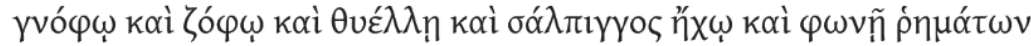

$19 b-20$

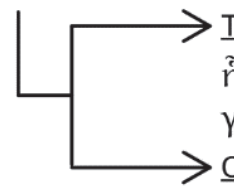

\section{The people's fear}

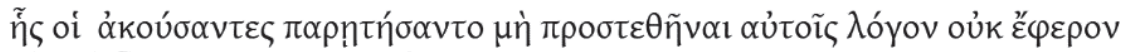

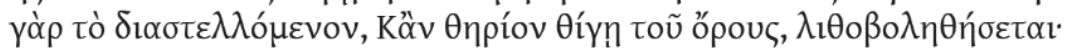

\section{Climax: Moses' fear}

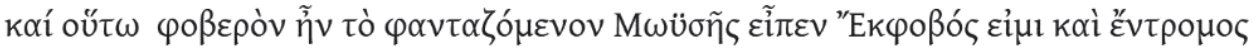

The joyous and advantageous situation under the new covenant

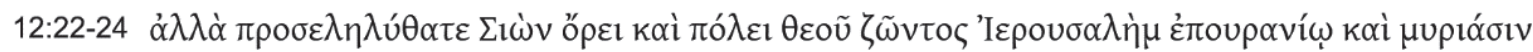

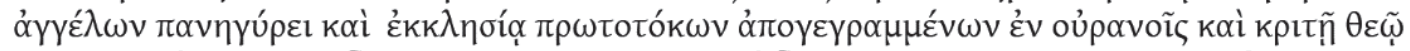

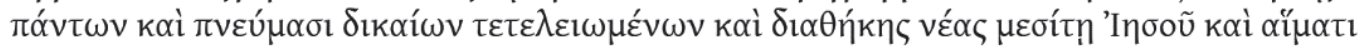

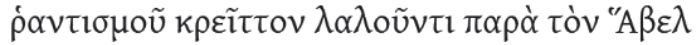

12:25-29 MAIN WARNING: React in the correct manner to God who is speaking Main exhortation to listen to God who speaks

25a В В

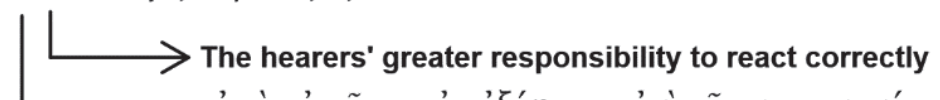

\section{Explicit call to thankful reaction}

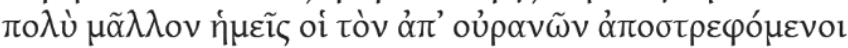

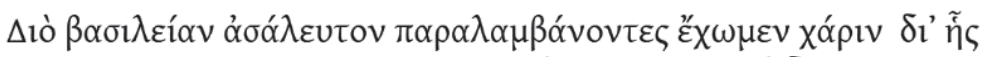

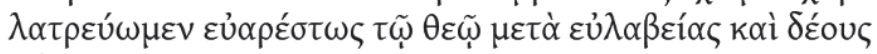

Implicit call to obedient endurance in the light of th
Old Testament quotation with reference to the future

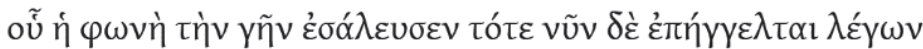

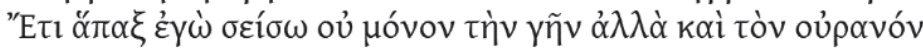
Explanation of Old Testament quotation

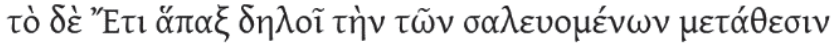

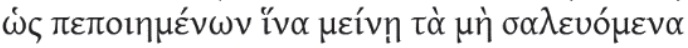

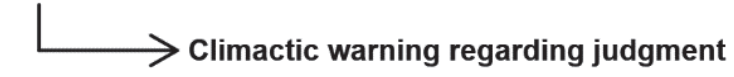

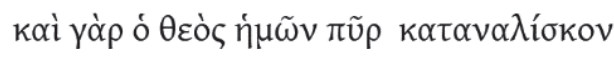


follows a threefold exhortation for each member of the community to continually be vigilant and protect one another in the face of possible apostasy. The unity of $12: 14-17$ is seen in the threefold repetition of $\mu$ í $\tau \iota$.

- 12:18-24 consists of two, semi-symmetrical, contrasting periods, namely 12:18-21 and 12:22-24, each containing seven and eight datives of destination, respectively. In essence, the two periods compare God's revelation at Sinai with his revelation under the new covenant. God's revelation at Sinai is described in such a way that it evokes fear and judgement, resulting in the idea that God cannot be approached. On the other hand, God's revelation under the new covenant is described in terms of joy and mercy, resulting in the encouragement to approach God through Jesus (cf. Cockerill 2012:646651). This contrast is beautifully indicated by the

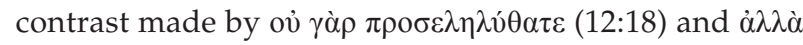
$\pi \rho о \sigma \varepsilon \lambda \eta \lambda v ́ \theta \alpha \tau \varepsilon(12: 22)$.

- 12:25-29 is seen by many as the fifth and final warning passage in Hebrews (cf. Guthrie 1994:133). Arguing from the hearers' superior situation as sketched in 12:18-24, the writer exhorts them to greater obedience to God's voice. He warns them in the most serious terms not to reject God who speaks from heaven, amongst others because he will (in words quoted from Hag 2:6) once more shake the heaven and the earth.

As a whole, 12:14-29 is a warning against apostasy in the light of the hearers' beneficial situation under the new covenant. In the light of this, the descriptive title 'Make sure you do not reject him who speaks more superiorly to you under the new covenant' can be given to 12:14-29.

Because 12:26 forms part of 12:25-29, more detailed analysis of the thought structure of these verses is necessary. The main clause is found right at the beginning in 12:25a:

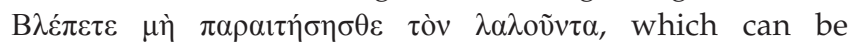
translated as 'Continually see to it that you do not refuse to listen to him [God] who is speaking at this present moment'. The writer exhorts his hearers to listen to God's superior revelation in his Son. The reason for this exhortation is given in 12:25b, which is introduced by the conjunction $\gamma \alpha$ ó $\rho$. This reason is made up of a factual condition ( $\varepsilon \hat{i}+$ indicative) that consists of a qal wahomêr argument, ${ }^{15}$ in which the writer explains the hearers' greater responsibility to respond appropriately to God's superior revelation through his Son. This is followed up by an implicit call to obedient endurance in the light of the future. The writer quotes Haggai 2:6 in 12:26, and explains his application of this quotation in 12:27. This is followed up by the strong inferential conjunction $\delta$ ió in 12:28, with which the writer introduces his explicit call to a grateful reaction, which he motivates with a climactic warning in 12:29.

Consequently, the best way forward to determine whether 12:26 indeed reveals the writer's conviction of God

15.Qal wahômer, meaning 'light and heavy', is a rabbinic principle where that which applies in a lesser situation naturally also applies in a greater situation (cf. Guthrie 2003:283). It is also referred to as an a fortiori argument. consummating by his word, is to analyse the quotation and explanation of Haggai 2:6 in Hebrews 12:26-27.

\section{An analysis of the quotation and explanation of Haggai 2:6 in Hebrews 12:26-27}

In its original Old Testament context, Haggai 2:6 forms part of Haggai 2:1-9, which contains the prophet's second prophetic utterance. Haggai had the commission to motivate the exiles that returned from Babylonia to rebuild the temple. His spurring on resulted in the commencement of the rebuilding, but soon afterward their work faltered. According to Haggai 2, the people became distraught at the inferior sight of the new temple in comparison to the splendour of Solomon's temple (Hag 2:1-3). The Lord therefore encouraged them via his prophet to be strong and to continue with the work. He assured them that he is with them (Hag 2:4-5). Moreover, he assured them that he will provide the needed resources for the rebuilding by doing great things:

For thus says the Lord of hosts: Yet once more, in a little while, I will shake the heavens and the earth and the sea and the dry land. And I will shake all nations, so that the treasures of all nations shall come in, and I will fill this house with glory, says the Lord of hosts. The silver is mine, and the gold is mine, declares the Lord of hosts. (Hag 2:6-8)

This 'eschatological earthquake language' (Meyers \& Meyers 1987:53) suggests that the Lord will shake the whole universe ${ }^{16}$ in the imminent future, ${ }^{17}$ just like he shook Mount Sinai when he gave the law (Taylor \& Clendenen 2004:158; cf. Keil \& Delitzsch 1954:191) (2:6), which will result in financial assistance from the nations (2:7-8). The shaking of nature will be the catalyst to get the nations to supply the necessary resources for the rebuilding of the temple. All this will result in the splendour of the temple being greater than the former $(2: 9) .{ }^{18}$

Turning to Hebrews 12:26 with Haggai 2:6's original context in mind, the writer's argument becomes clear. The

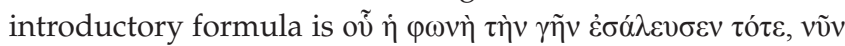
$\delta \dot{\varepsilon} \dot{\varepsilon} \pi \eta \dot{\gamma} \gamma \gamma \varepsilon \lambda \tau \alpha \iota \mathrm{l} \dot{\varepsilon} \gamma \omega \mathrm{v}$. The formula contains a contrast in time: 'then' ( $\tau$ ó $\tau$ ) is played off against 'now' (vṽv). In fact, Attridge (1989:380) correctly states that the whole introductory formula forms a chiasm. This can be illustrated as in Figure 5.

The verb of the 'then' part of the introductory formula is $\sigma \alpha \lambda \varepsilon v i \omega$. It usually refers to the action of causing something to move back and forth rapidly, namely 'to shake' (L\&N 16.7). The fact that $\sigma \alpha \lambda \varepsilon v \omega \omega$ is used together with $\tau \grave{\eta} v \gamma \tilde{\eta} v$ in Hebrews 12:26 suggests the literal use of the word, specifically in the form of an earthquake. This earthquake happened in the past and was brought about by 'his voice'. The immediate context of 12:18-21 recalls the natural phenomena of the theophany at Mount Sinai, which included 'the sound of [God's] words'

16.Taylor and Clendenen (2004:158) explain that the double merism created by 'heaven and earth' and 'sea and dry land' indicates that nothing will be unaffected.

17.The hiphil participle מַרְעִ is most probably a futurum instans (Verhoef 1987:102).

18.This interpretation of Haggai 2:6-9 is strengthened by Haggai 2:21-22, in which the Lord comforts Zerubbabel that he will shake the heavens and the earth and overthrow kingdoms. 


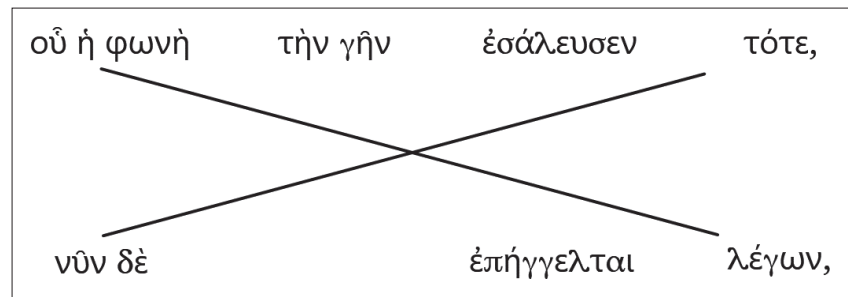

FIGURE 5: The chiastic structure of Hebrews 12:26a.

(Heb 12:19; cf. Dt 4:12) and an earthquake (Ex 19:18). ${ }^{19}$ Consequently, the 'then' part of the formula can be explained as a reference to God's theophany at Sinai.

The 'now' part of the introduction formula revolves around the

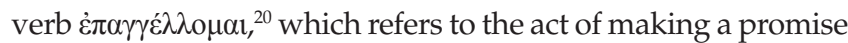
(L\&N 33.286). God is still the subject. The perfect tense of $\dot{\varepsilon} \pi \eta \dot{\gamma} \gamma \varepsilon \lambda \tau \alpha$ indicates that what God has promised in the past still has consequences for the present. His promise in the words of Haggai 2:6 has not yet been fully fulfilled. The promise is still in force. The use of 'now' (vov) in the introductory formula indicates that the hearers are presently being addressed with these words by God. Moreover, the use of 'now' links the promise with the immediate context of 12:22-24, which describes the hearers' advantageous situation under the new covenant. Consequently, the 'now' part of the formula can be explained as a reference to God's revelation through his Son.

In short, the introduction formula can be paraphrased as follows:

In the past, God's voice shook the earth at Sinai ... but now, through his Son, the following promise remains in force ... (author's own paraphrase)

The quotation of Haggai 2:6 that follows is taken from the $\mathrm{LXX},{ }^{21}$ which reads as follows:

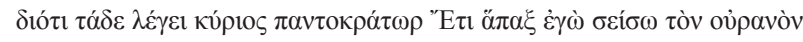

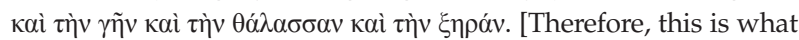
the Lord Almighty says: Yet once more I will shake the heaven and the earth and the sea and the dry land.]

The writer quotes this verse as follows in 12:26b:

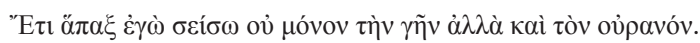

[Yet once more ${ }^{22}$ I will shake ${ }^{23}$ not only the earth but also the heavens.]

19.As Cockerill (2012:664) indicates, the LXX text of Exodus 19:18 interestingly enough does not contain a reference to the shaking of the Mount Sinai. Nonetheless, the idea of the earthquake accompanying the theophany at Sinai was common, as expressed i.a. in Psalm 68:8 (67:9 LXX).
ex

20.The present participle $\lambda \dot{\varepsilon} \gamma \omega$, used adverbially with $\dot{\varepsilon} \pi n \dot{\gamma} \gamma \varepsilon \lambda \tau \alpha$, can be viewed as a redundant or pleonastic participle which introduces direct speech (Blass \& Debrunner $1961: \$ 420$ ). Like most introductory formulae in Hebrews, the words of Haggai 2:6 are introduced with a verb of saying with God as subject. For a thorough study of the theme of God's speech in Hebrews' introductory formulae, see Coetsee and Jordaan (2015).

21.Although the writer's quotations do not conform to one version of the LXX (e.g. $L X X^{A}$ or $L X X^{B}$ ), it is universally accepted that he used a version of the LXX (cf. Docherty 2009:140; Gheorghita 2003:25; Rascher 2007:14-22). Rahlfs' edition of the LXX is quoted above.

22. The reference to the imminent 'in a little while' is not found in the LXX and is therefore not included by the writer of Hebrews.

23.The verb used in both Haggai 2:6 and the quotation in Hebrews 12:26 is $\sigma \varepsilon i \omega$, not

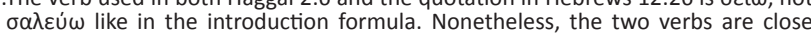
synonyms, as indicated by the fact that they share the same entry in Louw and Nida (16.7; cf. BDAG 2000:918).
The differences between the LXX-text and the quoted words found in Hebrews are striking. The writer deletes the reference to 'the sea and dry land', changes the word order of 'heaven' and 'earth' and places them in contrast to one another (ov̉ $\mu$ óvov ... $\dot{\alpha} \lambda \lambda \dot{\alpha} \kappa \alpha i)$. With these changes, the writer loosens Haggai 2:6 from its Old Testament context of the restoration of the temple and makes the eschatological interpretation more explicit and final. His argument is that God will someday ('once more') not only shake the earth as he shook it at Sinai, but he will shake both the earth and the heavens at the future and final eschatological day of judgement (cf. Cockerill 2012:666; Laansma 2008:9-18; TDNT 1976:7:70).

This interpretation is supported by $12: 27$, where the writer links the events that will happen 'once more' with the removal of 'things that have been made', resulting in the remaining of 'the things that cannot be shaken', namely God's kingdom (12:28).

At the end of the day, the writer's argument is quite simple: The eschatological shake of heaven and earth at the return of Christ and the consummation of all things will be far worse than the mere earthquake at Sinai (cf. 12:18-21). His hearers should therefore be grateful, devoted to God and vigilant, persevering in faith (12:28-29).

With all the above as background, we can return to the main question of this section: Does 12:26 say that God will consummate by his word? It does not seem so. The introductory formula in 12:26a does not lead one to understand God's voice as the instrument through which the visible heavens and earth will be shaken. ${ }^{24}$ The argument of 12:25-29 is not so much that God will consummate by his voice, but because of his voice. Because he promised that he will once more shake the earth and the heavens, the hearers can be sure that it will be so.

\section{A comparison with other references to consummation in Hebrews}

The only other explicit reference to the consummation in Hebrews is found in 1:10-12. As argued above, Hebrews 1:514 contains seven quotations from the Old Testament with which the writer argues for the Son's supremacy over the angels. In Hebrews 1:10-12, the writer quotes Psalm 102:2527 (LXX 101:26-28). The words contrast the Lord's eternality (Creator) with the creation's temporality:

You, Lord, laid the foundation of the earth in the beginning, and the heavens are the work of your hands; they will perish, but you remain; they will all wear out like a garment, like a robe you will roll them up, like a garment they will be changed. But you are the same, and your years will have no end.

What is once more of special interest here is the fact that the writer quotes these specific words in such a manner that God

24.2 Peter $3: 7$ possibly implies that the heavens and earth will be consummated by the word of God. According to the verse, the heavens and earth are stored up for fire 'by the same word', namely God's words of creation in Genesis 1 (2 Pt 3:5). God's word is the power behind both creation and the final judgement (cf. Davids 2006:271). 
says the specific words of Psalm 102 to his Son. Accordingly, Hebrews 1:10-12 proclaims the Son not only as Creator but

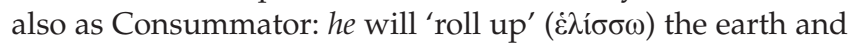
the heavens (which is a merism for the universe) and by implication he will cause them to be 'changed' (à $\lambda \lambda \alpha \dot{\sigma} \sigma \omega)$. Once more the emphasis falls on the sovereignty of the Son, as Cockerill (2012:114) aptly puts it: 'It will be no harder for the Son to remove this creation than for a human to fold up a coat or a blanket'

Although these words do not mention the Son's word or voice at consummation, it is striking to note that Hebrews ascribes certain roles to the Son that is usually ascribed to God in Scripture. The Son is not only God's agent of creation $(1: 2,10)$ and the one sustaining the universe by his powerful word (1:3), but he is also the one who will consummate everything (1:12).

\section{Conclusion}

The writer of Hebrews had the conviction that God will consummate creation at Christ's return, which will be accompanied by the final eschatological day of judgement (12:25-29). More specifically, Hebrews 1 reveals that the writer was convinced that the Son will consummate everything (1:10-12). However, this exegetical study could not prove that the writer of Hebrews had the conviction that God or Christ will consummate by his word.

\section{Creation, preservation and consummation in Hebrews}

This article set out to determine whether the writer of Hebrews had the conviction that God created by his word, preserves creation by his word and will consummate creation by his word. While exegesis of Hebrews 11:3 and 1:3 could confirm that the writer indeed had the conviction that God created and sustains creation by his word, exegesis of Hebrews 12:26 suggests the writer believed that God will consummate creation because of his word. His overall conviction regarding creation, preservation and consummation revolves around the Son and can be summarised as follows:

The Son was the agent of the creation of the spatial world and periods of time (1:2) that came to be by God's performative word (11:3); he continually sustains everything in the universe by his powerful word (1:3); and he will consummate everything (1:10-12) at his return as promised by God in Scripture (12:26). (author's own summary)

\section{Acknowledgements Competing interests}

The author declares that he has no financial or personal relationships which may have inappropriately influenced him in writing this article.

\section{References}

Allen, D.L., 2010a, Hebrews: The New American Commentary, vol. 35, Broadman \& Holman Publishers, Nashville, TN.

Allen, D.M., 2010b. “"Forgotten ages": Times and space in Heb 1.2', Bible Translator 61(3), 144-151.
Attridge, H.W., 1989, The Epistle to the Hebrews: Hermeneia, Fortress Press, Philadelphia, PA.

Bauer, W., Danker, F.W., Arndt, W.F. \& Gingrich, F.W., 2000, A Greek-English Lexicon of the New Testament and Other Early Christian Literature, Based on Walter Bauer's Griechisch-deutsches Worterbuch zu den Schriften des Neuen Testaments und de fohrchristlichen [sic] Literatur, 6th edn., University of Chicago Press, Chicago, IL.

Black, D.A., 1987, 'Hebrews 1:1-4: A study in discourse analysis', Westminster Theological Journal 49(1), 175-194.

Blass, F. \& Debrunner, A., 1961, A Greek grammar of the New Testament and other early Christian literature, Translated and edited by Robert W. Funk, University of Chicago Press, Chicago, IL.

Bruce, F.F., 1990, The Epistle to the Hebrews: The New International Commentary on the New Testament, Eerdmans, Grand Rapids, MI.

Calvin, J., 1853, Commentaries on the Epistle of Paul the apostle to the Hebrews, Translated and edited by J. Owen, Christian Classics Ethereal Library, Grand Rapids, MI.

Cockerill, G.L., 2012, The Epistle to the Hebrews: The New International Commentary on the New Testament, Eerdmans, Grand Rapids, MI.

Coetsee, A.J., 2014, Die sprekende God in die boek Hebreërs: 'n openbaringshistoriese studie, North-West University, PhD dissertation, Potchefstroom.

Coetsee, A.J., 2015, 'Streef na vrede met almal? Hebreërs 12:14 in perspektief', HTS Teologiese Studies/Theological Studies 71(1), Art. \#2949, 7 pages. https://doi.org/ 10.4102/hts.v71i1.2949

Coetsee, A.J., 2016, 'The unfolding of God's revelation in Hebrews 1:1-2a', HTS Teologiese Studies/Theological Studies 72(3), a3221. https://doi.org/10.4102/hts. v72i3.3221

Coetsee, A.J. \& Jordaan, G.J.C., 2015, 'Die tema van God se spraak in Hebreërs se inleidingsformules', In die Skriflig 49(1), Art. \#1852, 10 pages. https://doi. org/10.4102/ids.v49i1.1852

Cosby, M.R., 1998, The rhetorical composition and function of Hebrews 11 in light of example lists in ancient antiquity, Society of Biblical Literature Dissertation Series 156, Mercer University Press, Macon, GA.

Davids, P.H., 2006, The Letters of 2 Peter and Jude, Pillar New Testament Commentary, Eerdmans, Grand Rapids, MI.

Docherty, S.E., 2009, The use of the Old Testament in Hebrews: A case study in early Jewish Bible interpretation, Wissenschaftliche Untersuchungen zum Neuen Testament 260, Mohr Siebeck, Tübingen.

Ebert, D.J.' 1992 , 'The chiastic structure of the prologue to Hebrews', Trinity Journal 13(2), 163-179.

Eisenbaum, P.M., 1997, The Jewish heroes of Christian history: Hebrews 11 in literary context, Scholars Press, Atlanta, GA.

Ellingworth, P., 1993, The Epistle to the Hebrews: The New International Greek Testament Commentary, Eerdmans, Grand Rapids, MI.

Gheorghita, R., 2003, The role of the Septuagint in Hebrews: An investigation of its influence with special consideration to the use of Hab 2:3-4 in Heb 10:37-38, Wissenschaftliche Untersuchungen zum Neuen Testament 160, Mohr Siebeck, Tübingen

Guthrie, G.H., 1994, The structure of Hebrews: A text-linguistic analysis, Supplements to Novum Testamentum 73, Brill, Leiden.

Guthrie, G.H., 2003, 'Hebrews' use of the Old Testament: Recent trends in research', Currents in Biblical Research 1(2), 271-294.

Hughes, P.E., 1972, 'The doctrine of creation in Hebrews 11:3', Biblical Theology Bulletin 2, 64-77.

Hughes, P.E., 1977, A commentary on the Epistle to the Hebrews, Eerdmans, Grand Rapids, Ml.

Janse van Rensburg, J.J., 1980, 'Die ontleding van sintaktiese struktuur in die Griekste Nuwe Testament: Die ontwerp van 'n metode, geïllustreer met Romeine 8 : ' $\mathrm{n}$ hermeneutiese studie', PhD dissertation, PU for CHE, Potchefstroom.

Keil, C.F. \& Delitzsch, F., 1954, The Twelve Minor prophets, vol. II, Biblical Commentary on the Old Testament, Eerdmans, Grand Rapids, ML.

Kistemaker, S.J., 1984, Exposition of the Epistle to the Hebrews. New Testament Commentary, Baker Academic, Grand Rapids, MI.

Kittel, G. \& Friedrich, G. (eds.), 1976, Theological dictionary of the New Testament, vols. 1-10, Translator and editor G.W. Bromiley, Eerdmans, Grand Rapids, MI.

Koester, C.R., 2001, Hebrews: A new translation with introduction and commentary. The Anchor Bible, vol. 36, Yale University Press, New Haven, CT.

Laansma, J., 2008, 'Hidden stories in Hebrews: Cosmology and theology', in R. Bauckman, T. Hart, N. MacDonanld \& D. Driver (eds.), A cloud of witnesses: The theology of Hebrews in its ancient contexts, pp. 9-18, T\&T Clark, London.

Lane, W.L., 1991a, Hebrews 1-8: Word Biblical Commentary, vol. 47A, Thomas Nelson Publishers, Nashville, TN

Lane, W.L., 1991b, Hebrews 9-13: Word Biblical Commentary, vol. 47B, Thomas Nelson Publishers, Nashville, TN.

Lewicki, T., 2004, "Weist nicht ab den Sprechenden!": Wort Gottes und Paraklese im Hebräerbrief, Paderbornes theologische Studien 41, Ferdinand Schöningh, Paderborn.

Liddell, H.G., Scott, R. \& Jones, H.S., 1996, A Greek-English Lexicon, 9th edn., with revised supplement, Clarendon Press, Oxford.

Louw, J.P. \& Nida, E.A. (eds.), 1996, Greek-English lexicon of the New Testament based on semantic domains, 2nd edn., vols. 1 \& 2, United Bible Societies, New York. 
MacArthur, J.F., 2007, Hebrews: Christ - Perfect Sacrifice, Perfect Priest, Thomas Nelson, Nashville, TN.

Mackie, S.D., 2008, 'Confession of the Son of God in the exordium of Hebrews', Journal for the Study of the New Testament 30(4), 437-453.

MacLeod, D.J., 2005, 'The finality of Christ: An Exposition of Hebrews 1:1-4' Bibliotheca Sacra 162, 210-230.

Meier, J.P., 1985, 'Structure and Theology in Heb 1:1-14', Biblica 66(2), 168-189.

Metzger, B.M., 1994, A textual commentary on the Greek New Testament, 2nd edn. United Bible Societies, London.

Meyers, C.L. \& Meyers, E.M., 1987, Haggai, Zechariah 1-8, The Anchor Bible: A new translation with introduction and commentary, Doubleday \& Company, Garden City, New York.

Moffatt, J., 1924, A critical and exegetical commentary on the Epistle to the Hebrews: The International Critical Commentary, T\&T Clark, Edinburgh.
Rascher, A., 2007, Schriftauslegung und Christologie im Hebräerbrief, Beihefte zur Zeitschrift für die neutestamentliche Wissenschaft 153, De Gruyter, Berlin.

Taylor, R.A. \& Clendenen, E.R., 2004, Haggai, Malachi, The New American Commentary: An exegetical and theological exposition of Holy Scripture, vol. 21A, B\&H Publishing Group, Nashville, TN.

Thompson, J.W., 2008, Hebrews: Paideia, Baker Academic, Grand Rapids, MI.

Verhoef, P.A., 1987, The books of Haggai and Malachi, New International Commentary on the Old Testament, Eerdmans, Grand Rapids, MI.

Webster, J., 2009, 'One who is Son: Theological reflections on the exordium to the Epistle to the Hebrews', in R. Bauckham, D.R. Driver, T.A. Hart \& N. MacDonald (eds.), The Epistle to the Hebrews and Christian Theology, pp. 69-94, Eerdmans, Grand Rapids, MI.

Wider, D., 1997, Theozentrik und Bekenntnis: Untersuchungen zur Theologie des Redens Gottes im Hebräerbrief, Beihefte zur Zeitschrift für die neutestamentliche Wissenschaft 87, De Gruyter, Berlin. 